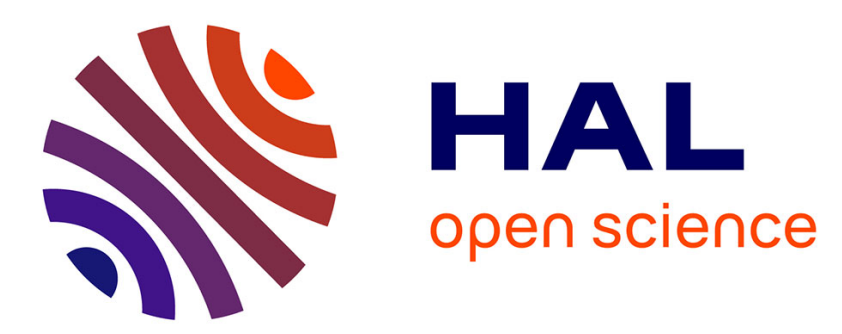

\title{
Improved SiO2-coatings against high temperature sulphidation by internal stress reduction
}

\author{
R. Hofman, J. Westheim, T. Fransen, P. Gellings
}

\section{To cite this version:}

R. Hofman, J. Westheim, T. Fransen, P. Gellings. Improved SiO2-coatings against high temperature sulphidation by internal stress reduction. Journal de Physique IV Proceedings, 1993, 03 (C9), pp.C9865-C9-871. 10.1051/.jp4:1993989 . jpa-00252431

\section{HAL Id: jpa-00252431 https://hal.science/jpa-00252431}

Submitted on 1 Jan 1993

HAL is a multi-disciplinary open access archive for the deposit and dissemination of scientific research documents, whether they are published or not. The documents may come from teaching and research institutions in France or abroad, or from public or private research centers.
L'archive ouverte pluridisciplinaire HAL, est destinée au dépôt et à la diffusion de documents scientifiques de niveau recherche, publiés ou non, émanant des établissements d'enseignement et de recherche français ou étrangers, des laboratoires publics ou privés. 


\title{
Improved $\mathrm{SiO}_{2}$-coatings against high temperature sulphidation by internal stress reduction
}

\author{
R. Hofman, J.G.F. Westheim, T. Fransen( $\left.{ }^{\star}\right)$ and P.J. Gellings
}

University of Twente, Department of Chemical Technology, Division of Corrosion Science and Inorganic Chemistry, P.O. Box 217, 7500 AE Twente, The Netherlands.

\begin{abstract}
Alloys such as AISI 304 and AISI 321 stainless steels and Incoloy $800 \mathrm{H}$ can be protected against high temperature corrosion by means of amorphous $\mathrm{SiO}_{2}$-coatings deposited by metal organic chemical vapor deposition (MOCVD). The coated alloys are only attacked locally after exposure to a $19 \% \mathrm{H}_{2}, 1 \% \mathrm{H}_{2} \mathrm{~S}, 1.5 \% \mathrm{H}_{2} \mathrm{O}$, Ar bal. environment at $823 \mathrm{~K}\left(p_{\mathrm{S}_{2}}=1.2 \times 10^{-9}\right.$ bar and $\left.p_{\mathrm{O}_{2}}=9.3 \times 10^{-29} \mathrm{bar}\right)$. The crack density observed after sulphidation is identical for silica deposited onto all metallic substrates. Decohesion of amorphous silica coatings from AISI 304 is observed, when the coating thickness exceeds $1.7 \mu \mathrm{m}$, while coatings on Incoloy $800 \mathrm{H}$ are adherent up to $4 \mu \mathrm{m}$. These phenomena can be explained by the fact that the adhesion is a function of the chemical interactions between the metal and the coating, whereas crack formation is only a function of the internal stresses in the coating. Two methods are studied to reduce the coating failure by means of a reduction of internal stresses in the coating, the first is changing the deposition process and the second is reducing the thermal mismatch between the coating and the metal.
\end{abstract}

\section{Introduction.}

Much work [1] has been carried out to improve the corrosion resistance of alloys in coal gasification environments by coatings. Mainly pack cemented $\mathrm{Cr}$ and $\mathrm{Al}$ diffusion coatings and $\mathrm{MeCrAl}(\mathrm{Y})$-plasma sprayed coatings $(\mathrm{Me}=\mathrm{Fe}$ or $\mathrm{Co}$ ) have been tested in these environments. Less work has been performed on the deposition of ceramic coatings by electrophoresis, sol-gel, and chemical or physical vapor deposition. Hofman et al. [2] deposited $\mathrm{SiO}_{2}$ coatings by metal organic chemical vapor deposition (MOCVD) on several alloys to improve the corrosion resistance in simulated coal gasification environments. Degradation of these coated alloys did not occur by bulk diffusion of sulphur through the coating, but by inward diffusion of sulphur and outward diffusion of metal ions along cracks in the coating. The inner product layer was always a $\mathrm{CrS}$ scale, and the outward growing layer was a mixed $\mathrm{FeS} / \mathrm{CrS}$ scale. Morssinkhof et al. [3] used a MOCVD-technique to deposit $\mathrm{Al}_{2} \mathrm{O}_{3}$ coatings on Incoloy $800 \mathrm{H}$ in order to improve its sulfidation resistance. Hydroxyl groups in the $\mathrm{Al}_{2} \mathrm{O}_{3}$ coating were suggested to be responsible for a higher stress than calculated on basis of the thermal mismatch between the coating and the metal and therefore a more rapid degradation was observed.

$\left(^{\star}\right)$ To whom all correspondence should be addressed. 


\section{Experimental.}

Protective $\mathrm{SiO}_{2}$ coatings were deposited on several alloys by the MOCVD technique. DiAcetoxyDi-t-ButoxySilane (DADBS) (Petrarch) was used as a metal organic precursor and the process was carried out at atmospheric pressure. The equipment employed is shown in figure 1. All coatings were deposited under identical conditions; the deposition temperature was $833 \mathrm{~K}$, the gas flow through the saturator was $241 . \mathrm{h}^{-1}$ (NTP), the dilutant (nitrogen) gas flow was $241 . \mathrm{h}^{-1}$ (NTP), and the temperature of the saturator was $355 \mathrm{~K}$. The dilutant gas flow could be saturated partially with water. Experimental results concerning the deposition of the $\mathrm{SiO}_{2}$ coating have been published elsewhere [4].

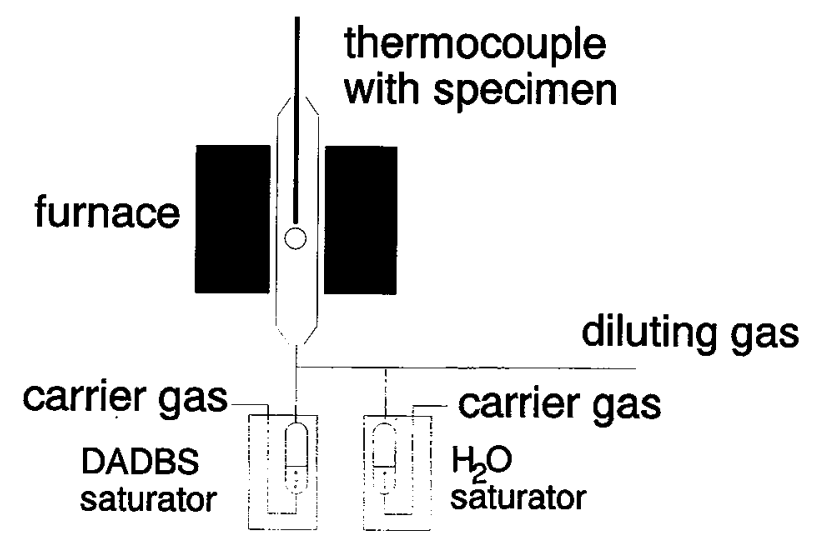

Fig. 1. - Schematic drawing of the atmospheric MOCVD-equipment.

The sulphidation experiments were carried out in a spring balance (Fig. 2), and a full description is found elsewhere [2]. A $19 \% \mathrm{H}_{2}, 1 \% \mathrm{H}_{2} \mathrm{~S}, 1.5 \% \mathrm{H}_{2} \mathrm{O}, \mathrm{Ar}$ (bal.) gas was used to simulate a coal gasification environment. This gas composition corresponds with $p_{\mathrm{S}_{2}}=$ $1.2 \times 10^{-9}$ bar and $p_{\mathrm{O}_{2}}=9.3 \times 10^{-29}$ bar at $823 \mathrm{~K}$.

Coatings were deposited on AISI 304 and AISI 321 stainless steels and onto Incoloy $800 \mathrm{H}$. Prior to deposition all specimens were polished successively on 25, 6, 1 and $0.25 \mu \mathrm{m}$ diamond paste and finally etched in a solution of $5 \% 3 \mathrm{M}$ nitric acid in ethanol for $15 \mathrm{~min}$. The surface morphology and cross sections of the specimens were examined with scanning electron microscope (SEM) (JEOL 35CF) and the elemental composition was determined with energy dispersive X-ray analysis (EDX) (KEVEX DELTA CLASS III).

Some AISI 321 and Incoloy $800 \mathrm{H}$ specimens were oxidized in air for $24 \mathrm{~h}$ at $1133 \mathrm{~h}$ prior to deposition of the silica coating.

\section{Results and discussion.}

$\mathrm{SiO}_{2}$-coated alloys are always attacked locally upon exposure to the sulphidizing atmosphere at $823 \mathrm{~K}$ (see Fig. 3). At this relatively low temperature reaction of the coating with either the aggressive gas or the metal does not take place. Bulk diffusion of sulphur and/or metal 


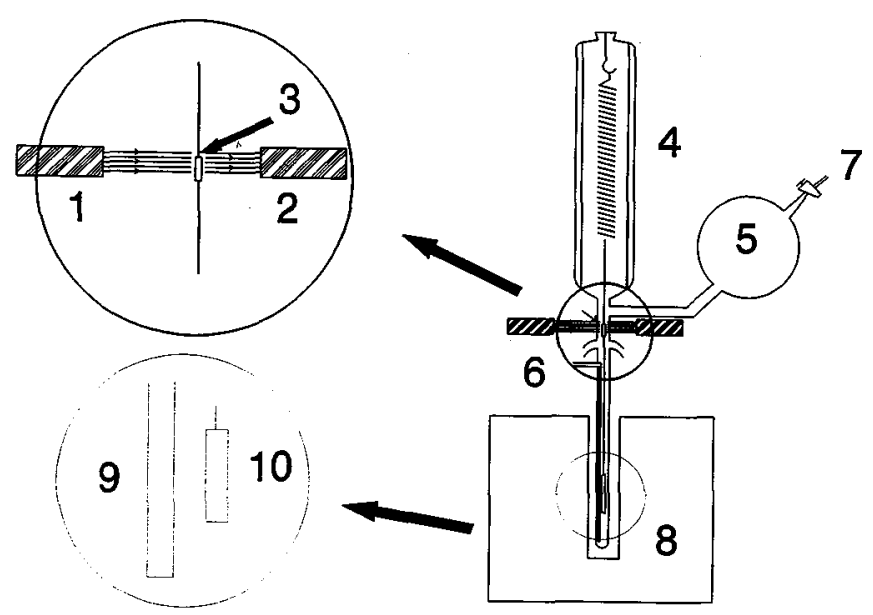

Fig. 2. - Schematic drawing of the spring balance: $1=$ laser emitter; $2=$ laser receiver; $3=$ interceptor; $4=$ spring at constant temperature; $5=$ gas buffer; $6=$ gas inlet; $7=$ gas outlet; $8=$ furnace; $9=$ thermocouple and $10=$ specimen.

through the coating and crystallisation of the amorphous coating can also be neglected [5]. Therefore, degradation of the coated alloys only occurs by diffusion of sulphur and metal ions along cracks [2]. Crack formation in the ceramic coating is caused by internal stresses in the coating $\left(\sigma_{\mathrm{ox}}\right)$. These stresses are a sum of stresses due to thermal mismatch between the coating and the metal $\left(\sigma_{\text {therm }}\right)$ and stresses due to the deposition process $\left(\sigma_{\text {dep }}\right)$.

$$
\sigma_{\mathrm{ox}}=\sigma_{\mathrm{therm}}+\sigma_{\mathrm{dep}}
$$

The stress caused by thermal mismatch can be calculated by [6]

$$
\sigma_{\text {therm }}=E_{\mathrm{ox}} \Delta \alpha \Delta T
$$

where $E_{\mathrm{ox}}$ denotes the Young's Modulus of the coating, $\Delta \alpha$ the difference of thermal expansion coefficient of the metal $\left(\alpha_{\mathrm{m}}\right)$ and the coating $\left(\alpha_{\mathrm{ox}}\right)$ and $\Delta T$ the difference between the temperature after deposition $\left(T_{\text {low }}\right)$ and the deposition temperature $\left(T_{\text {dep }}\right)$. For the metal/ $\mathrm{SiO}_{2}$ system the calculated thermal stress is about $0.6 \mathrm{GPa}$ (Tab. I).

The crack density in $\mathrm{SiO}_{2}$ coated Incoloy $800 \mathrm{H}$, and AISI 304 after sulphidation at $823 \mathrm{~K}$ is almost identical (Fig. 4). The stress in the coating is obviously independent of the metal, since the expansion coefficients of all the metals used are almost equal (Tab. I).

To increase the sulphidation resistance by the $\mathrm{SiO}_{2}$ coatings necessitates that the crack density has to be reduced. This is only possible when the stress in the coating can be reduced. This can be achieved by reducing the difference between thermal expansion coefficients of silica and metal substrate. Since the expansion coefficient of commercial alloys and the ceramic coating are fixed values, thermal mismatch stresses can only be reduced by the introduction of one or more layers between the metal and the coating. Stresses generated during the deposition can be lowered by modifying the deposition process. 


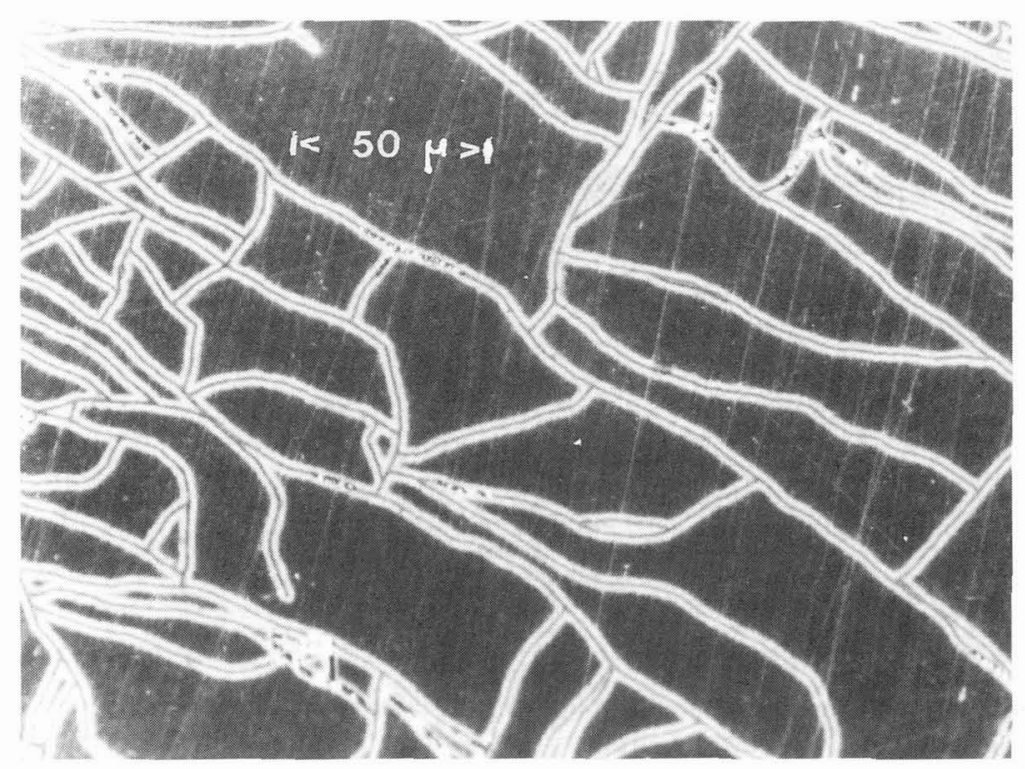

Fig. 3. - A locally attacked coated AISI 321 specimen after exposure to the sulphidizing environment for $400 \mathrm{~h}$ at $823 \mathrm{~K}$.

Table I. - The thermal expansion coefficient and Young Modulus of oxides and metals, together with the calculated thermal mismatch between oxide and metal.

\begin{tabular}{|l|l|l|l|}
\hline Material & $\begin{array}{l}\text { Expansion } \\
\text { coefficient } \\
\left(10^{6} \mathrm{~K}^{-1}\right)\end{array}$ & $\begin{array}{l}\text { Young } \\
\text { Modulus } \\
(\mathrm{GPa})\end{array}$ & $\begin{array}{l}\sigma_{\text {th }} \\
\left(\mathrm{SiO}_{2}\right)(\mathrm{calc}) \\
(\mathrm{GPa})\end{array}$ \\
\hline $\mathrm{Cr}_{2} \mathrm{O}_{3}$ & $\mathrm{ca} .8$ & $>100$ & 0.30 \\
\hline $\mathrm{ZrO}_{2}$ & 7.5 & 48 & 0.27 \\
\hline $\mathrm{SiO}_{2}(\mathrm{a})$ & 0.5 & 75 & 0 \\
\hline $\mathrm{AISI} 304^{2}$ & 18 & 190 & 0.69 \\
\hline Iicoloy 800 H & 15 & 196 & 0.57 \\
\hline
\end{tabular}

Ceramic layers with an expansion coefficient value between that of $\mathrm{SiO}_{2}$ and of the metal are $\mathrm{Cr}_{2} \mathrm{O}_{3}$ and $\mathrm{ZrO}_{2}$ (Tab. I). $\mathrm{CrO}_{3}$ intermediate layers can be formed easily on the alloys by 


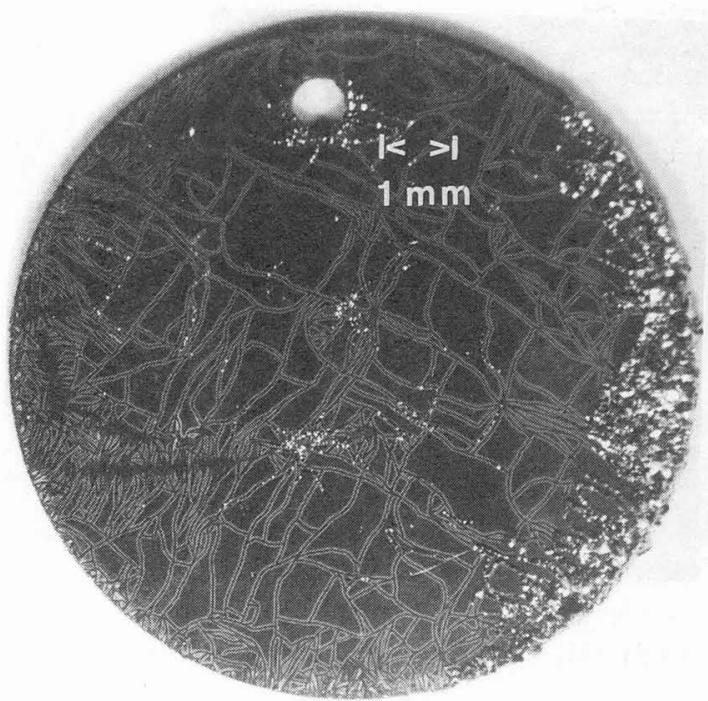

a)

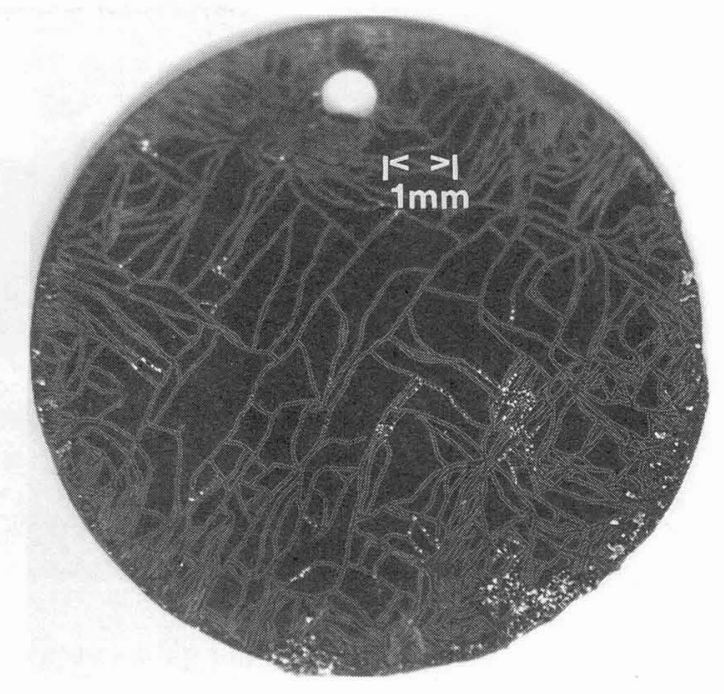

b)

Fig. 4. - The crack density of several specimens after exposure to the sulphidizing environment for $400 \mathrm{~h}$ at $823 \mathrm{~K}(\mathrm{a}=\mathrm{AISI} 304, \mathrm{~b}=$ Incoloy $800 \mathrm{H})$.

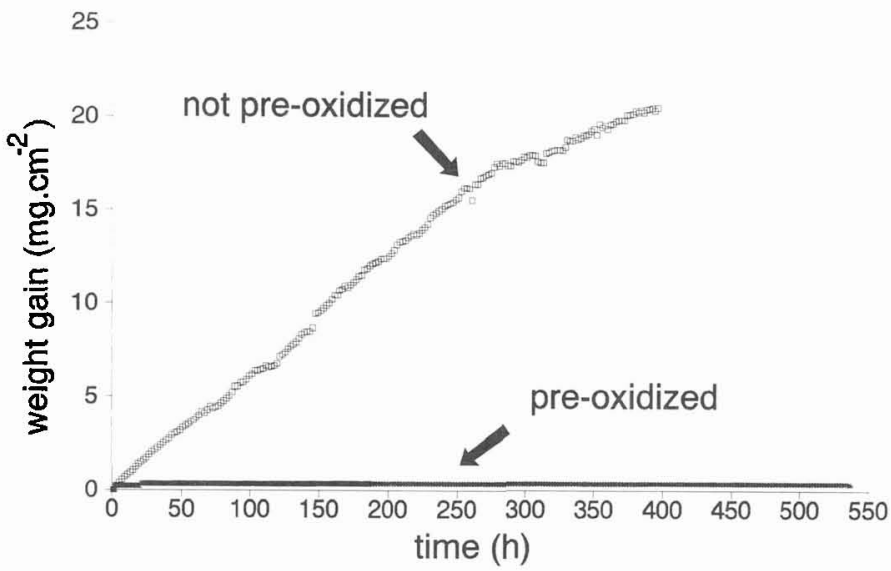

Fig. 5

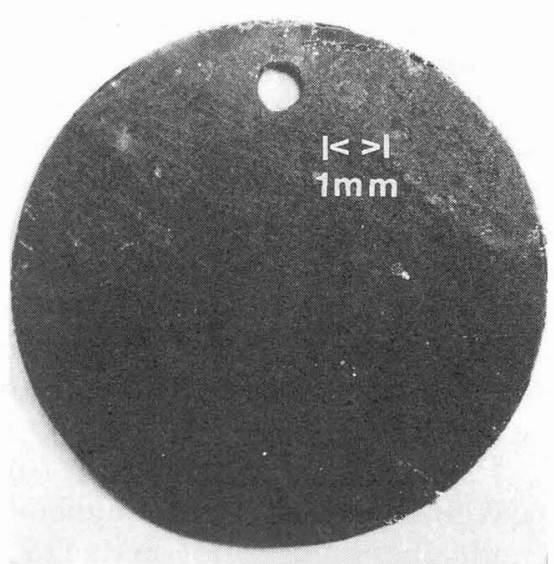

Fig. 6

Fig. 5. - The weight gain of a silica coated preoxidized and a coated non-preoxidized Incoloy $800 \mathrm{H}$ specimen during corrosion in the sulphidizing environment at $823 \mathrm{~K}$.

Fig. 6. - A diminished crack density is observed in $\mathrm{SiO}_{2}$ coated AISI 321 when water vapour was added during the deposition process.

an oxidation step prior to deposition and preoxidation in air for $24 \mathrm{~h}$ at $1123 \mathrm{~K}$ results in improved sulphidation resistance (Fig. 5).

The MOCVD-process was modified by adding a defined water vapour partial pressure to the metal organic vapour stream. The crack density in the $\mathrm{SiO}_{2}$ coatings was dimin- 


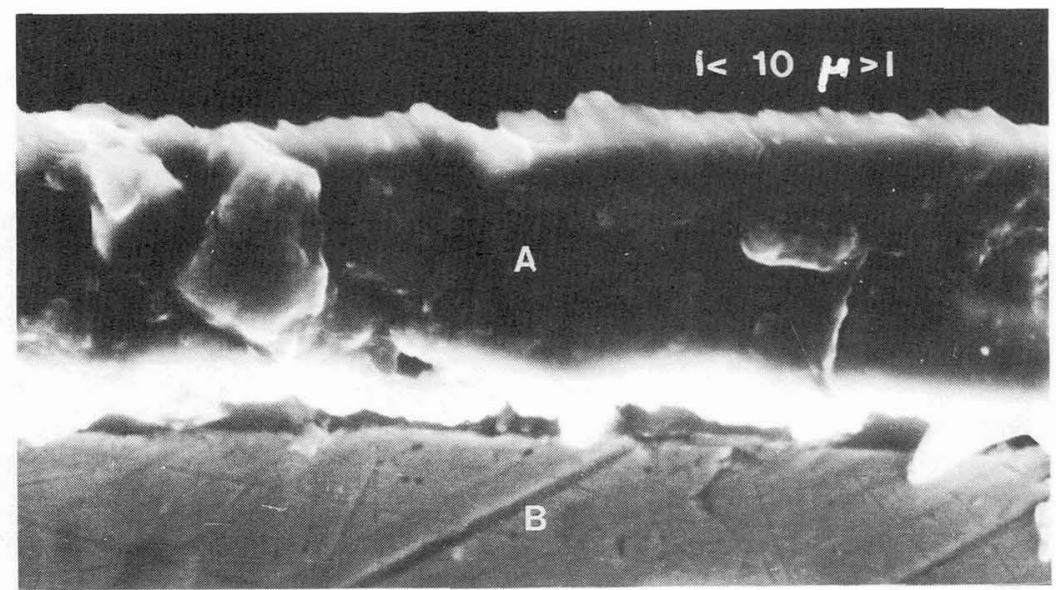

Fig. 7. - A cross section of an adherent silica coating on Incoloy $800 \mathrm{H}$, with a layer thickness of $13.5 \mu \mathrm{m}$ ( $\mathrm{a}=$ coating, $\mathrm{b}=$ alloy).

ished by this water addition (Fig. 6). The mechanism, however, is not very well understood. Morssinkhof et al. [3] suggested that the inclusion of OH-groups in the coating leads to a larger internal stress in the coating and, thus to a disminished protection. Van Glabbeek et al. [7] and Mackor [8] also related an alteration in the behaviour of ceramic coatings to the presence of $\mathrm{OH}$-groups.

The development of thick protective coatings is hindered not only by the formation of cracks in the ceramic coating, but also by delamination of the coating from the metal. Therefore the critical thickness, above which non-adherent coatings are formed, has been estimated for $\mathrm{SiO}_{2}$-coatings on AISI 304 and Incoloy $800 \mathrm{H}$. $\mathrm{SiO}_{2}$ coatings are always adherent up to $4 \mu \mathrm{m}$ thickness on Incoloy $800 \mathrm{H}$ and up to $1.7 \mu \mathrm{m}$ thickness on AISI 304. Deposition of thicker coatings on both substrates is possible, but this depends on the surface cleanliness of the substrate. Although adherent $13.5 \mu \mathrm{m}$ thick silica coatings could be deposited on Incoloy $800 \mathrm{H}$, the maximum measured thickness of adherent $\mathrm{SiO}_{2}$ coatings on AISI 304 never exceeded $2.2 \mu \mathrm{m}$.

Matting et al. [9] and Vlack [10] reviewed a variety of adhesion mechanisms, including mechanical interlocking of roughened surfaces, chemical reaction or alloying with the substrate, and adhesion or cohesion due to Van der Waals forces, epitaxy etc.. Mechanical interlocking is not likely to play a major role, because both the Incoloy $800 \mathrm{H}$ and AISI 304 specimens were subjected to the same surface finishing step, leading to the same surface roughness. Adhesion by weak Van der Waals forces would not lead to great differences in coating adhesion on the different alloys, while epitaxy does not occur when amorphous coatings are deposited on polycrystalline substrates. One of the only remaining possibilities to explain to difference in adhesion for different alloys, is a chemical interaction between the coating and the metal.

\section{Conclusions.}

$\mathrm{SiO}_{2}$ coated metallic alloys such as AISI 304 and AISI 321 stainless steel and Incoloy $800 \mathrm{H}$ are always attacked locally by sulphur when they are exposed to a gas mixture simulating coal gasification environments. This originates from the formation of cracks in the coating where 
the density is independent of the substrate alloy. Cracking can be reduced by lowering the stress in the coating. $\mathrm{A} \mathrm{Cr}_{2} \mathrm{O}_{3}$ layer between coating and metal reduces the thermal mismatch stress, while the stresses caused by the deposition process can be diminished by adding water vapour to the process gas. The improved sulphidation resistance caused by the addition of water vapour might be due to modification of the amount of $\mathrm{OH}$-groups in the coating. The crack density in the ceramic coating is independent of the alloy. The adhesion of $\mathrm{SiO}_{2}$ coatings is better on Incoloy $800 \mathrm{H}$ then on AISI 304, which might be explained by chemical interactions between the metal and the coating.

\section{Acknowledgements.}

This work was supported by the Technology Foundation (STW). Mr. B. Geerdink is gratefully thanked for his technical assistance and the many discussion. Mr. H. Tonnaer is gratefully thanked for performing experiments.

\section{References}

[1] LANG E., Coatings for High Temperature Applications (Applied Science Publishers, London) 1983.

[2] Hofman R., Westheim J.G.F., Fransen T., Gellings P.J., Mater. Manufact. Process. 7 (1992) 227.

[3] MORSsINkHOF R.W.J., The Deposition of Thin Alumina Films on Steels by MOGVD, PhD-Thesis university of Twente (Enschede, 1991).

[4] Hofman R., Morssinkhof R.W.J., Westheim J.G.F., Fransen T., Gellings P.J., accepted for publication in Mater. Manufact. Process.

[5] Coley K.S., Tuson A.T., SAunders S.R.J., BennetT M.J., KNights C.F., Mater Sci. Eng. A 121 (1989) 461.

[6] EVANS H.E., Mater. Sci. Eng. A 120 (1989) 139.

[7] VAN GLABBEEk J.J., VAN DE LeeST R.E., Thin Solid Films 201 (1991) 137.

[8] MACKOR A., results presented at SON electrochemical meeting Lunteren, 31 oct 1991).

[9] Matting H.A., Steffens H.D., Metall. 17 (1963) 583, 905, 1213.

[10] VLACK L.H., The Metal-Ceramic Boundary, presented at the 1964 Metals Materials Congress, Technical Report N. P (10-1-64) (Philadelphia, Penn, 1964). 